\title{
Authoritary Leadership, Compensation On Employee Performance
}

\author{
$1^{\text {st }}$ Muhammad Nashar ${ }^{1}, 2^{\text {nd }}$ Ryani D Parashakti ${ }^{2}, 3^{\text {nd }}$ Agustinus Haryadi DP ${ }^{3}$ \\ $\left\{\right.$ muhammad_nashar@mercubuana.ac.id ${ }^{1}$, ryani@mercubuana.ac.id ${ }^{2}$, \\ agustinus.haryadi@mercubuana.ac.id $\left.{ }^{3}\right\}$ \\ Universitas Mercu Buana, Indonesia ${ }^{123}$
}

\begin{abstract}
This study aims to determine the effect of authoritarian leadership style, and compensation on employee performance in Manufacturing Company Banking Equipment PT. Titan Sarana Niaga. This sampling method is a quantitative research, with a sample of 99 respondents, the sampling method is a non-probability sampling and the sample technique used is saturated samples. Analytical technique using multiple linear regression analysis. The results of this study indicate that authoritarian leadership styles are positive and significantly affect the performance of employees. Compensation has a positive and significant influence on employee performance in this company. The result of compenataion have a strong relationship level, this means that if the leadership style of authoritarian and compensation is increased it will result in high employee performance
\end{abstract}

Keywords: leadership style, authoritarian compensation, employee performance

\section{Introduction}

Human Resources are essentially one of the capital and hold the most important role in achieving company goals, because they have the talent, energy, and creativity that is needed by the company to achieve its goals. Therefore companies need to manage Human Resources as well as possible. Because the key to the success of a company is not only the superiority of technology and the availability of funds. But human factors are also the most important factor. (1). PT. Titan Sarana Niaga is one of the companies engaged in Banking Equipment in Indonesia. Banking Equipment or what is known as Bank Equipment and Equipment. PT. Titan Sarana Niaga was pioneered by a Family Company called "Titan Advantage Group". The business continues to grow and currently has 30 Service Points throughout Indonesia with a total population of almost 500 employees throughout Indonesia. There are several phenomena that appear in the business of Banking Equipment, the aspect of human resources is an important concern for the organization, because the success or failure of a company depends on empowering human resources that can produce good or bad performance. As a result of a decrease in employee performance which is shown from the attendance list of employees starting from frequent late, often permission, illness, or not entering without information. There are complaints from customers regarding poor and declining performance. There are also complaints that occur from employees of compensation received by employees is not appropriate, not in accordance with the expectations of promises given, not on time. This happens because the low job satisfaction of employees is influenced by the style of 
leadership and compensation that is applied and given to employees so that there is or does not influence the two indicators with employee performance.

In connection with the background stated above, the formulation of the research problem is as follows.

1. Does the Authoritarian Leadership Style affect the performance of the employees of PT. Titan Sarana Niaga?

2. Does compensation affect the performance of employees of PT. Titan Sarana Niaga?

\section{Literature review}

\subsection{Human Resource Management}

Human resource management (HRM) is a science or method of how to regulate the relationship and role of resources (labor) owned by individuals efficiently and effectively and can be used optimally so that a common goal is achieved by the company, employees and society to the maximum. HRM is based on a concept that every employee is a human being not a machine and not merely a business resource. Human resource management also concerns the design and implementation of planning systems, employee preparation, employee development, career management, performance evaluation, employee compensation and good employment relations. Human resource management involving all decisions and management practices that mem $\mathrm{p}$ engaruhi human resources directly. (Source:).

\subsection{Leadership}

Leadership is the most important factor in an organization. According to Sutikno (2014), "There are almost as many definitions of leadership as the number of people who have tried to define them" (2)(3)(4). While according to Suwanto (2014) states that, "Leadership is the ability to influence groups towards achieving goals" (5)(6)(7)(8)(9).

\subsection{Compensation}

Kadarisman (2012) argues that, "compensation is an award to employees in a fair and equitable manner for work performance that has been issued for the achievement of organizational goals" (10). According to Sedarmayanti (2011) states that compensation is "everything that is received by employees as a reward for their work" (11),(12)(13).

\subsection{Performance}

Mangkunegara (2011) said: "Performance is the result of work in quality and quantity achieved by an employee in carrying out his duties in accordance with the responsibilities given to him" (14)(15)(16)(17)(18)(19)(20). Another opinion according to Nawawi (2013) suggests that, "a person's performance is determined by the interaction of the ability and motivation to carry out work". 


\section{Research Model}

Based on the formulation of the problem and the research framework described above, the research hypothesis can be seen from logical framework as follows:

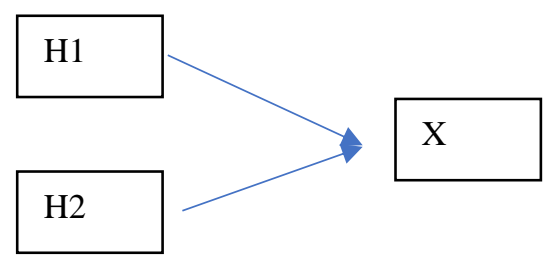

$\mathrm{H}_{1}$ : Authoritarian leadership style has a positive effect on the performance of employees of PT. Titan Sarana Niaga.

$\mathrm{H}_{2}$ : Compensation has a positive effect on the performance of employees of PT. Titan Sarana Niaga.

\section{Research Methodology}

In preparing this proposal, the unit of analysis is the Manufacturing Banking Equipment company PT. Titan Sarana Niaga. The research that will be conducted is quantitative research, namely systematic scientific research on parts and phenomena and their relationships. This study is a type of causal research that aims to investigate the possible causes, find the facts that might be caused by certain data. This study is to examine the effect of Authoritarian Leadership Style and Compensation on Employee Performance of PT. Titan Sarana Niaga.

In order to get research results that are in accordance with the objectives of the study, the correct analysis method is needed . Testing is done using SPSS 20. SPSS software (Statistical Package for the Social Sciences) is a computer program used to analyze statistics.

\subsection{Research Population and Samples}

\section{Population}

The population in this study focused on active employees who were listed as permanent employees in 2017 at PT. Titan Sarana Niaga, totaling 99 people at the Head Office and Factory.

\section{Sample}

To determine the sample size in this study researchers used saturated samples, where the number of samples remained with the number of 99 people referred to as respondents. Base on calculation it is known that the highest mean number is 4.202 , shown in the GK 4 indicator with the question about "Leaders trying to develop a new atmosphere". While the lowest mean 
is 3,232 shown in GK 13 indicator with questions about "Leaders appreciate employee initiatives ". also based on calculation it is known that the highest mean number is 4.111 shown in the indicator KOM 3 with questions about "Salaries provided by companies make me more enthusiastic to work". While the lowest mean is 3.131 indicated on the KOM 8 indicator with questions about " I get office allowance, transport money, food allowance from the company". it is known that the highest mean number is 4,121 indicated in the KIN 4 indicator with the question " Always try to improve quality in working with the ability possessed to achieve good results ". While the lowest mean is 3.566 shown in the KIN 11 indicator with questions about "I comply with all rules and guidelines for work safety determined by the company ".

\subsection{Data Analysis Method Validity test}

Validity test is used to test the extent to which the accuracy of a measuring device can reveal the concept of the symptoms / events being measured. If the correlation of each factor is positive and the magnitude is above 0,5 then the factor is declared valid (21). The test results are as follows, For leadership style instruments with GK1-GK15 indicator the value of validity is $>0.5$, then for compensation instruments with KOM1-5 indicator the value of validity is $<0.5$ while KOM6-KOM15 has a validity value $>0.5$. then for the performance instrument with the KIN1-KIN15 indicator the value of validity is $>0.5$.

Due to the presence of instruments that do not meet the standard of validity, the KOM1KOM5 indicator must be discarded and the validity test is repeated. The following are the results of retesting their validity. It can see the overall value of the instrument is $>0,5$. So it can be concluded that the statements on the questionnaire are valid or feasible in defining the overall variable. So that the indicators of this research variable are valid.

\subsection{Reliability Test}

This reliability testing is done by finding the value of cronbach's alpha . a construct or variable is said to be reliable if it gives Cronbach alpha value> 0.60 (21)(22)(23). The following are the results of the reliability test.

it can be seen that all variables show numbers more than 0.6 . So it can be concluded that all statement items from the three variables to be examined are reliable.

\subsection{Classical Assumption Test Results Normality Test Resulr}

Normality testing is done to see in the regression model, whether the residual values produced are normally distributed or not. In the normality test, the researcher used a normal probability plot graph on the histogram graph as follows. the points spread around the line and follow the diagonal line, it can be concluded that the residual values resulting from the regression are normal and meet the assumptions of normality

The normality test can also be seen using the histogram graph. Data that is normally distributed is shown by a histogram chart pattern that follows the curve (bell), then the regression model meets the assumptions of normality. 


\subsection{Multicollinearity Test Results}

Multicollinearity testing is done by looking at the VIF (Variant Inflated Factor) value with tolerance value, that the VIF value is less than 10 and the tolerance value is greater than 0.1 so it can be concluded that there is no multicollinearity or high correlation between independent variables.

\subsection{Heterocedasticity Test Results}

Heterocedasticity testing is done by looking at the scatter plot graph . The scatter diagram above does not form a certain pattern. Thus it can be said that regression does not experience heteroscedasticity so that the regression model is feasible to be used to predict performance based on the input of independent variables.

\subsection{Multiple Linear Regression Test Results}

This form of multiple regression analysis can also be applied in this study. The numbers used to compile this equation are taken from the Unstandardized Coefficients numbers in the table coefficients, along with the data the Unstandardized Coefficients values for each variable, so that the equation becomes

$$
\begin{aligned}
& \mathrm{Y}=\mathbf{a}+\mathbf{b X}_{1}+\mathbf{b X}_{2}+\mathbf{c} \mathrm{X}_{3}+\mathrm{e} \\
& \quad \text { Become: } \\
& \mathrm{Y}=\mathbf{8 . 1 2 2}+(\mathbf{0 . 9 9 2}) \mathrm{X}_{1}+(\mathbf{1 , 3 5 8}) \mathrm{X}_{2}+\mathrm{e}
\end{aligned}
$$

\subsection{Hypothesis Test Results F Test Results}

The $\mathrm{F}$ test is conducted to determine whether all the independent variables included in the model have a joint or simultaneous influence on the dependent variable. This F statistic test is a test that is needed in testing the hypothesis proposed in this study. The test results on SPSS output can be seen in the Sig ANOVA table value. it can be seen that the number Sig in the ANOVA table is 0,000. This value is smaller than the level set at 0,05 . From this, based on the testing criteria, it can be concluded that the leadership style and compensation variables jointly influence performance.

\section{Test Results $\mathbf{t}$}

In this $\mathrm{t}$ test it shows that there is a significant relationship between the independent variables on the dependent variable if sig $<0,05$. Likewise, the opposite if sig $>0,05$ then this indicates there is no significant relationship between one dependent variable to the independent variable.

a. The leadership style variable has sig $0,000<0,05$ meaning that there is a significant effect on performance.

b. The compensation variable has sig $0,000<0,05$ meaning that there is a significant effect on performance. 


\section{$\mathbf{R}^{2}$ Test Results}

The results of testing the coefficient of determination (R2) is done to measure how far the ability of the regression model to explain the dependent variable.

The correlation value between the leadership style variables $\left(\mathrm{X}_{1}\right)$ and compensation $\left(\mathrm{X}_{2}\right.$ ) on performance $(\mathrm{Y})$ is 0.868 . It can be concluded that there is a strong correlation or relationship between leadership style variables and compensation with performance, because the value is adjusted $\mathrm{R}$ square above 0,5 .

\section{Discussion}

\section{Authoritarian Leadership Style Influence on Performance}

The influence of authoritarian leadership style on employee performance based on the results of data analysis results of the $t$ test for leadership style variables has a value of 0,000 . So it can be concluded that there is an influence between authoritarian leadership styles on employee performance.

\section{Compensation Effect on Performance}

The effect of compensation on employee performance based on the results of data analysis results of the $t$ test for the compensation variable has a value of 0,000 . It can be concluded that there are significant between compensation to employee performance, the greater the compensation received by employees, it will be the employee's performance will be better.

\section{Conclusions and suggestions \\ Conclusion}

Based on the results of the previous analysis and discussio, the following conclusions can be drawn:

1. The style of authoritarian leadership has a positive effect on employee performance. This shows that good leadership can place its leadership style in accordance with the existing situation and conditions and the better leadership style, the employee's performance will increase .

2. Compensation has a positive effect on employee performance. This shows that the better and increased compensation given to employees, the employee's performance will increase. 


\section{References}

1. Syahu Sugian O. Company Management . Jakarta: Gramedia Library. 2011;

2. Sutikno. Corporate Human Resource Management - Leadership . Jakarta: Bumi Aksara. 2014;

3. Mondiani T. " The Effect of Leadership and Compensation on Employee Performance at PT. PLN (Persero) Semarang ". Thesis. UPJ Semarang . 2012;

4. Thoha M. Leadership and Management. Revision of College Books . Jakarta: PT. Raja Grafindo Persada. 2010;

5. Grant AM. Reversing the Extraverted Leadership Advantage: The Role of Employee Proactivity (vol 54, pg 656, 2011). Acad Manag J [Internet]. 2011;54(4):656.

Available from: https://static1.squarespace.com/static/55dcde36e4b0df55a96ab220/t/55e5f374e4b0453 9eab51172/1441133428448/GrantGinoHofmann_Reversing.pdf\%0Apapers3://publica tion/uuid/F2E463DA-F220-4831-BCD0-8EEDA678EE81

6. Arief Chaidir Abdillah FW. "The Effect of Leadership, Job Stress, Work Discipline, and Compensation with Employee Performance at the Primary Tax Office in Boyolali”. Essay, Surakarta Faculty of Economics and Business. 2011;

7. Arif Rahman Hakim MY. " Analysis of the Effect of Leadership Style, Work Motivation, and Compensation on Teacher's Performance at PPMI High School in Surakarta " . Thesis. Surakarta Faculty of Economics and Business. 2014;

8. Skakon J. " Are leaders" well-being, behaviors and styles associated with affective well-being of their employees? A systematic review of three decades of research "Work, Health, and Organizations . 24 (2), 2." 2010.

9. Suwanto. Human Resource Management - leadership style . Bandung: CV. Alfabeta. 2014

10. Kadarisman. Compensation Management . Jakarta: Raja Grafindo Persada. 2012.

11. Sedarmayanti. Human Resources and Work Productivity (employee performance and compensation) . Bandung: Mandar Forward. 2011;

12. Sedarmayanti. Building and Developing Leadership and Improving Performance to Achieve Success . Bandung: PT. Refika Aditama. 2011;

13. Sutrisno E. Human Resource Management - Employee Performance . Jakarta: Kencana Prenada Media. 2009;

14. Hasibuan M. Human Resource Management . Jakarta: PT. Earth Literacy. 2012;

15. Mangkunegara AP. Company Human Resource Management . Bandung: PT. Teenager Rosdakarya. 2014;

16. Megawati R. " The Effect of Financial Compensation, Leadership Style and Work Motivation on Employee Performance at PT Asia Macro in Karanganyar Regency r" . Thesis. Tirtayasa Faculty of Economics and Business. 2012; 
17. Modiani. Human Resource Management - Type of Leadership Style . Jakarta: Salemba Empat. . 2012;

18. Razali, Mukhlis Yunus TRIP. “ Influence Of Leadership, Compensation And Competence To Work And Satisfaction, Motivation Of Work And Its Impact On Performance Of Employees KESRA SETDA ACEH BUREAU". Economy Management . 4 (2), 2. 2015;

19. Liden RC, Wayne SJ, Liao C, Meuser JD. Servant leadership and serving culture: Influence on individual and unit performance. Acad Manag J. 2014;57(5):1434-52.

20. Rolasmana. " The Influence of Leadership Style, Decision Making Effectiveness, and Incentive Compensation for the Performance of Employees in the Financial Section of Supermarkets in Tanjung Pinang ". Thesis. Tanjung Pinang School of Business Economics. 2013;

21. Sugiyono. Understanding Qualitative Research . Bandung: CV. Alfabeta. 2012;

22. Sugiyono. Qualitative and Quantitative Research Methods . Bandung: CV. Alfabeta. 2009;

23. Ghozali I. Ghozali, Imam. (2009). Application of Multivariate Analysis with the SPSS Program . Semarang: Diponogoro University. 2009; 